\title{
PANDANGAN ABDULLAH SAEED PADA KONSEP NASKH MANSUKH (ANALISIS SURAH AN-NUR AYAT 2)
}

\author{
Muhammad Nasrullah \\ Universitas Islam Negeri Sunan Ampel Surabaya, Indonesia \\ Email: nrul889@gmail.com
}

\begin{abstract}
The theory of naskh mansükh is still a debate between scholars regarding agreement and rejection. And among scholars who agree on the concept of nasikh mansükh in the Qur'an, each has their own criteria in determining the concept of nasikh. One of the scholars who agrees is Abdullah Saeed, a contemporary commentator who offers a new method of interpreting the Qur'an, namely the contextualist method. In this paper, researchers are interested in studying the concept of nasikh mansükh according to Saeed through the problems that occur in naskh mansükh Surah An-Nur verse 2. According to Abdullah Saeed, the concept of naskh mansükh gives a very logical idea that the applicable law may experience cancellation for the sake of fulfill the needs of the people due to different conditions and situations, if in the past the Qur'an was still decreasing then the solution from Allah to meet the needs of the people was to cancel the existing law by lowering new laws or nasikh mansükh, but now that the verses of the Qur'an have been coming down, it is to fulfill the needs ummah is by reciting the Qur'an. And Abdullah Saeed made naskh mansūkh as a first step to contextualize the law of the Qur'an.
\end{abstract}

Kata kunci: Abdullah Saeed; Naskh Mansūkh; Surah An-Nur. 


\section{Abstrak}

Teori nasikh mansūkh sampai saat ini masih menjadi perdebatan di kalangan ulama tentang kesepakatan dan penolakan. Dan diantara para ulama yang menyepakati konsep naskh mansükh dalam Al-Qur'an, masing-masing memiliki kriteria sendiri-sendiri dalam menentukan konsep nasikh. Salah satu ulama yang sependapat adalah Abdullah Saeed, seorang komentator kontemporer yang menawarkan metode baru penafsiran AlQur'an, yaitu metode kontekstual. Dalam tulisan ini, peneliti tertarik untuk mengkaji konsep naskh mansūkh menurut Saeed melalui permasalahan yang terjadi pada naskh mansükh Surah AnNur ayat 2. Menurut Abdullah Saeed, konsep naskh mansūkh memberikan a Pemikiran yang sangat logis bahwa hukum yang berlaku dapat mengalami pembatalan demi pemenuhan kebutuhan masyarakat karena kondisi dan situasi yang berbeda, jika pada masa lalu Alquran masih menurun maka solusi dari Allah untuk memenuhi kebutuhan masyarakat. Tadinya membatalkan hukum yang ada dengan menurunkan hukum baru atau nasikh mansū kh, tetapi sekarang ayat-ayat Alquran telah diturunkan, maka untuk memenuhi kebutuhan ummat adalah dengan membaca Alquran. Dan Abdullah Saeed menjadikan naskh mansükh sebagai langkah awal untuk mengkontekstualisasikan hukum Al-Qur'an.

Kata Kunci: Abdullah Saeed, Naskh Mansukh dan Surat al-Nur

\section{Pendahuluan}

Zina adalah setiap persetubuhan yang terjadi bukan karena pernikahan yang sah, bukan karena syubhat, dan bukan pula karena pemilikan (budak). Secara garis besar pengertian ini 
Muhammad Nasrullah, Pandangan Abdullah Saeed Pada Konsep Naskh

telah disepakati oleh para ulama Islam, meskipun mereka masih berselisih pendapat tentang penerapan hukumannya. ${ }^{1}$

Maraknya kasus perzinaan yang terjadi dan terus meningkat pada kalangan anak-anak muda bahkan juga orang yang sudah menikah sangatlah meresahkan masyarakat. Karena hal itu dikhawatirkan akan merusak moral seseorang. Disamping rusaknya moral sesorang, dengan terjadinya kasus perzinaan yang terus meningkat ditakutkan akan menimbukan beberapa penyakit diantaranya HIV, AIDS, Sipilis dan lain sebagainya. Dan jika hal itu sudah terjadi, tentunya saja orang yang merasa dirugikan bukan hanya si pelaku, namun orang disekitarnya pasti merasa dirugikan. Apalagi jika si pelaku tertangkap tangan dalam melakukan perzinaan ataupun terkena penyakit dari apa yang telah dia lakukan, pasti keluarga, daerah, bahkan kerabat-kerabatnya akan merasa malu dan terbebani atas apa yang telah dia lakukan.

Di dalam agama Islam kasus perzinaan dianggap sebagai suatu perbuatan yang sangat terkutuk dan dianggap juga sebagai tindak kejahatan yang disebut sebagai jarimah. Islam dengan tegas melarang perzinaan. Dengan adanya larangan pasti juga ada

${ }^{1}$ Zainudin Ali, Hukum Pidana Islam (Jakarta: Sinar Grafika, 2009), h. 37. 
sebuah hukuman jika ada yang melanggar larangan tersebut. Penerapan hukumannya Allah SWT. bersabda bahwasanya hukuman bagi pelaku zina adalah didera seratus kali. ${ }^{2}$ Dan Rasulullah juga telah bersabda bahwasanya hukuman bagi pelaku zina dibagi ke dalam dua bagian yaitu zina muhshan dan ghairu muhshan. Untuk yang muhshan adalah dera dan rajam sementara untuk yang ghairu muhshan adalah dera dan diasingkan keduanya selama satu tahun dari daerahnya. ${ }^{3}$ Berdasarkan hukuman yang telah dijelaskan di dalam al-Qur'an dan as-Sunnah terdapat beberapa perbedaan pendapat oleh para ulama' dalam hal hukuman terhadap pelaku zina.

Hukuman dari perzinaan tersebut dijelaskan dalam Surah An-Nur ayat 2. Berkaitan dengan banyaknya problematika hukuman yang diberikan oleh para pezina, maka dari itu penulis ingin mengkaji tentang konsep naskh mansükh pada Surah AnNur ayat 2 tersebut. Namun penulis juga ingin memfokuskan pembahasan konsep naskh mansūkh menurut Abdullah Saeed. Yang mana Abdullah Saeed ialah seorang cendekiawan yang mengembangkan teori tafsir kontekstual. Disamping itu dalam 2009), h. 234.

${ }^{2}$ Sayyid Sabiq, Fikih Sunnah 4(Jakarta: Cakrawala Publishing,

${ }^{3}$ Hasan Kamil al-Lathowi, Fiqh Muamalah ala Madzhab al Imam Malik (Beirut: Toba'ah al-Aula, 1970), h. 220. 
Muhammad Nasrullah, Pandangan Abdullah Saeed Pada Konsep Naskh

sebuah jurnal Abdullah Saeed juga membahas tentang permasalahan naskh mansükh tentang zina dalam Surah An-Nur ayat 2 .

\section{Biografi Abdullah Saeed}

Abdullah Saeed merupakan seorang professor Studi Arab dan Islam di Universitas Melbourne, Australia. Saat ini dia menjabat sebagai Direktur Pusat Studi Islam Kontemporer di universitas tersebut. Saeed lahir di Maladewa, dari keturunan suku bangsa Arab Oman yang bermukim di pulau Maladewa. Pada tahun 1977, dia hijrah ke Arab Saudi untuk menunt ut ilmu di sana. Di Arab Saudi, dia belajar bahasa Arab dan memasuki beberapa lembaga pendidikan formal di antaranya Institut Bahasa Arab Dasar (1977-1979) dan Institut Bahasa Arab Menengah (19791982) serta Universitas Islam Saudi Arabia di Madinah (19821986).

Di tahun berikutnya, Saeed meninggalkan Arab Saudi untuk belajar di Australia. Di negeri kanguru tersebut, Saeed menyelesaikan studi dari strata satu hingga program doktoralnya. Gelar Sarjana Strata Satu (Master of Arts Preliminary) diperolehnya dalam Jurusan Studi Timur Tengah di Universitas Melbourne Australia (1987). Master dalam Jurusan Linguistik 
Terapan (1988-1992) dan doktoralnya dalam Studi Islam (19921994) diselesaikan di universitas yang sama. Saeed kemudian mengabdi di universitas yang sama hingga sekarang. ${ }^{4}$ Selain itu, dia juga aktif dalam berbagai organisasi dan seminar internasional.

Di Australia, Saeed mengajar Studi Arab dan Islam pada program strata satu dan program pasca sarjana. Di antara mata kuliah yang diajarkan adalah Ulum al-Qur'an, Intelektualisme Muslim dan Modernisasi, Pemerintahan dan Peradaban Islam, Keuangan dan Perbankan Islam, Hermeneutika al-Qur'an, Metodologi Hadis, Ushul Fiqh, Kebebasan Beragama di Asia, Islam dan Hak Asasi Manusia, dan Islam dan Muslim di Australia. Berkat keuletannya, Saeed berhasil meraih gelar professor dalam bidang Studi Arab dan Islam pada tahun 2003. Di tahun 2010, dia dipilih menjadi anggota Akademi Kemanusiaan Australia. ${ }^{5}$

Saeed dinilai sebagai seorang yang berwawasan luas, professional, dan konsisten terhadap keilmuan. Dia banyak diikutsertakan dalam pertemuan dan seminar-seminar

${ }^{4}$ Sheyla Nichlatus Sovia, "Interpretasi Kontekstual: Studi Pemikiran Hermeneutika Al-Qur'an Abdullah Saeed," Dialogia: Jurnal Studi Islam dan Sosial, IAIN Pomorogo (2016), h. 40-41.

${ }^{5}$ Annas Rolli Muchlisin, "Penafsiran Kontekstual: Studi Atas Konsep Hierarki Nilai Abdullah Saeed," Maghza : Jurnal UIN Sunan Kalijaga Yogyakarta Vol. 1, No. 1 (Januari-Juni 2016), h. 21. 
Muhammad Nasrullah, Pandangan Abdullah Saeed Pada Konsep Naskh

internasional. Saeed juga terlibat dalam berbagai kelompok dialog lintas kepercayaan, antara Kristen dan Islam, dan antara Yahudi dan Islam. Selain itu, Saeed tergabung dalam Asosiasi Professor Asia Institut Universitas Melbourne dan Akademi Agama Amerika. Saeed juga menjadi anggota editorial jurnal skala internasional seperti Jurnal Studi al-Qur'an di Inggris, Jurnal Studi Islam Pakistan, dan Jurnal Studi Arab, Islam, dan Timur Tengah Australia.

Di tengah kesibukannya tersebut, dia masih menyempatkan waktu untuk menulis. Banyak sekali karya yang dihasilkan Saeed, berikut karya-karya beliau yang berkaitan dengan Alquran, Reading the Qur'an in the TwentyFrirst Century: A Conextualist Approach (New York: Rautledge, 2013), The Qur'an: An Introduction (New York: Routledge, 2008), 15 Interpreting the Qu'an: Toward a Contemorary Approach (Routledge, 2006), Contemporary Approaches to Qur'an in Indonesia, sebagai editornya (Oxford University Press, 2005). ${ }^{6}$

Selain kajian terkait Alquran, Saeed juga menulis terkait beberapa hal seperti dalam karyannya: Islam in Australia

${ }^{6}$ Imron Mustofa, "Kritik Metode Kontekstualisasi Penafsiran Al-Qur'ân Abdullah Saeed," Islamica: Jurnal Studi Keislaman 10, No. 2 (1 Maret 2016), h. 467. 
(Sydney: Allen dan Unwin, 2003), Fredom of Religion: Apostasy and Islam (Ashgate Publishing, 2004), Muslim Australians: Their Beliefs, Practices and Instititions (Commonwealth Government, 2004), menjadi editor bersama S. Akbarzadeh dalam karya Islam and Political Legitimacy (Curson, 2003) dan Muslim Communities in Australia (University of New Sauth Waless Press, 2002) ${ }^{7}$

Selain dalam bentuk buku, tulisan Saeed juga sering dimuat dalam jurnal, ensiklopedia, dan bab dalam buku, seperti "Muslim in the West and Their Attitudes to Full Participating in Western Societies: Some Reflection" dalam buku Religion and Multicultural Citizenship diterbitkan di Cambridge oleh Cambridge University Press, "Trends in Contemporary Islam: A Preliminary Attempt at a Classification" dalam The Muslim World (vol. 97) Juli 2007, "Women, Gender and Islamic Banks" dalam Encyclopedia of Women and Islamic Cultures (vol. 4) diterbitkan oleh Brill Publishing tahun 2006, "Contextualizing" dalam The Blackwell Companion to the Qur'an oleh Fethi Mansouri (ed) diterbitkan oleh Oxford University Publishing tahun 2006, "Fazlur Rahman: A Framework for Interpreting the

${ }^{7}$ Mustofa, "Kritik Metode Kontekstualisasi Penafsiran AlQur'ân Abdullah Saeed,", h. 47 
Muhammad Nasrullah, Pandangan Abdullah Saeed Pada Konsep Naskh

Ethico-Legal Content of the Qur'an" dalam Modern Muslim Intellectuals and the Qur'an oleh Suha Taji-Farouki (ed) diterbitkan tahun 2004 oleh Oxford University Press, "Nurcholish Madjid and the Interpretation of the Qur'an: Religious Pluralism and Tolerance" ditulis bersama A.H. John dalam Modern Muslim Intellectuals and the Qur'an oleh Suha Taji-Farouki (ed) diterbitkan tahun 2004 oleh Oxford University Press, dan tulisantulisan lainnya yang tidak mungkin dicantumkan semua di sini.

Abdullah Saeed juga sangat aktif terlibat dalam seminar baik berskala nasional maupun internasional. Berikut tulisan Saeed yang dipresentasikan di beberapa seminar, antara lain "Towards a More Inclusive View of the Religious 'Other': a Muslim Perspective" dalam kuliah perdamaian di Universitas Otago Dunedin New Zealand tahun 2007, "Development of the Concept of Jihad in Islam" dalam seminar hukum kemanusiaan internasional dan hukum Islam di Palang Merah Queensland Brisbane tahun 2007, "How to Bridge the Information Gap Between Islam and the West?" dalam Konferensi Internasional Islam dan Barat di Institut Hubungan Diplomasi dan Luar Negeri Kuala Lumpur Malaysia tahun 2007, "Muslims in the West between Participants and Isolationist" di Universitas Sultan Qaboos Oman tahun 2004, "Religious Reconciliation in 
Volume 2, Number 2, Juli - Desember 2020

e-ISSN 2716-4241

ISSN 2723-2344

Indonesia: Inclusivist versus Exclusivist" dalam Seminar Akademu Kemanusiaan Australia tahun 2000, dan masih banyak lagi seminar yang dia ikuti. ${ }^{8}$

\section{Teori Naskh Mansūkh}

Naskh mansūkh merupakan salah satu kaidah dalam ulumul qur'an yang penting untuk dipelajari dan diketahui baik untuk fuqahā', uṣuliyyin ataupun para mufassir. Secara bahasa naskh memiliki bermacam-macam makna.

Berikut merupakan beberapa pengertian naskh secara etimologis, yaitu : penghapusan/pembatalan (al-izalah atau alibthal), pemindahan (alnaql), pengubahan/penggantian (al-ibdal), dan pengalihan (al-tahwil atau al-intiqal). ${ }^{9}$ Berkaitan dengan pengertian tersebut, maka nasikh (isim fạil) diartikan sesuatu yang membatalkan, menghapus, memindahkan, dan memalingkan. Sedangkan mansūkh (isim maful) adalah sesuatu yang dibatalkan, dihapus, dipindahkan, diganti, dan dipalingkan.

${ }^{8}$ Annas Rolli Muchlisin, “Penafsiran Kontekstual', h. 21-22.

${ }^{9}$ Supiana dan M. Karman, Ulumul al-Quran dan Pengenalan Metode Tafsir (Bandung: Pustaka Islamika, 2002), h. 149. 
Muhammad Nasrullah, Pandangan Abdullah Saeed Pada Konsep Naskh

Sebagaimana dalam pengertian etimologi, naskh dalam terminologipun memiliki pengertian yang berbeda-beda, sebagaimana pendapat yang mengatakan bahwa naskh adalah mengangkat atau menghapus hukum syara' dengan dalil hukum (khitab) yang lain. ${ }^{10}$ Sementara sebagian ulama yang lain mengatakan bahwa definisi nasakh menurut istilah adalah mengangkat hukum syar'i dengan dalil syara' yang lain, ini dapat dipandang sebagai definisi yang cermat. Sejalan dengan bahasa Arab yang mengartikan kata naskh sama dengan meniadakan dan mencabut, beberapa ketentuan hukum syari'at yang oleh al-Syari' (Allah dan Rasul-Nya) dipandang tidak perlu di pertahankan, dicabut dengan dalil-dalil yang kuat dan jelas serta berdasarkan pada kenyataan yang dapat dimengerti, untuk kepentingan suatu hikmah dan hanya diketahui oleh orang-orang memilki ilmu sangat dalam. ${ }^{11}$ Ada juga yang berpendapat bahwa naskh adalah mengangkat hukum syara' dengan dalil syara' yang datang kemudian dengan menghilangkan 'amal pada hukum-hukumnya atau menetapkannya.

${ }^{10}$ Manna' al-Qattan, Mabahis fi 'Ulum al-Qur'an terjemahan Muzakir (Jakarta: Pustaka Al-Kautsar, 2008), h. 232.

${ }^{11}$ Subhi Salih, Mabahis fii Ulum al-Qur'an (Beirut: Dar al-'Ilm lil Malayin, 1988),h. 260. 
Sedangkan pengertian mansūkh adalah obyek atau hukum yang dihapus, beliau mencontohkan dengan mengambil permasalahan penghapusan hukum wasiat oleh hukum warisan. ${ }^{12}$

Dari beberapa definisi diatas yang paling mendekati kebenaran dengan pengertian naskh adalah definisi yang pertama dan terakhir, yakni mengangkat hukum syara' dengan dalil syara' yang lain yang datang kemudian. Maksudnya hukum atau undang - undang yang terdahulu dibatalkan atau dihapus oleh undang undang baru, sehingga undang-undang yang lama tidak berlaku lagi. Perlu diketahui di sini bahwa yang dibatalkan adalah hukum syara' bukan hukum akal dan pembatalan itu karena adanya tuntutan kemaslahatan.

Naskh mansükh merupakan salah satu pembahasan dalam ulumul quran yang banyak menarik perhatian para ulama. Sehingga penjelasan tentang naskh mansükh dalam kitab-kitab ulumul quran cukup terperinci. Salah satunya seperti pengkategorian surat-surat dalam Alquran dari ada atau tidaknya naskh mansūkh dalam surat tersebut.

${ }^{12}$ Al-Qattan, Pengantar Studi Ilmu Al-Qur'an,, h. 286. 
Muhammad Nasrullah, Pandangan Abdullah Saeed Pada Konsep Naskh

Ulama Islam mensyaratkan bahwa naskh baru bisa dilakukan manakala memenuhi aturan/syarat yang telah ditentukan. Imam Muhammad Abu Zahrah contohnya, dalam menaskh suatu nash mengajukan empat syarat;13 ${ }^{13}$ pertama, hukum yang di-mansûkh tidak di ikuti oleh ungkapan yang menunjukkan atas keabadian hukum yang terkadung di dalamnya. Contoh, persaksian orang yang dikenakan sanksi karena menuduh orang lain berbuat zina, tidak akan diterima sebelum ia bertaubat. Sebabnya, nash yang menet apkan hukum ini diikuti oleh ungkapan yang menunjukkan atas berlakunya hukum tersebut selamalamanya.

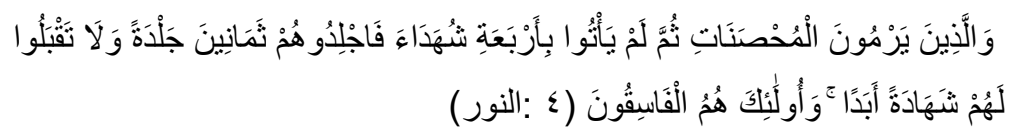

Kata abadan (selamanya) dalam ayat di atas menunjukkan bahwa hukum ini lestari dan tidak berubah.

Kedua, hukum yang mansūkh itu tidak tergolong masalah - masalah yang telah disepakati oleh para cerdik pandai atas

${ }^{13}$ Asmu'i, "Studi Kritis Atas Konsep Nâsikh-Mansûkh Abdullahi Ahmed An-Na'im," Kalimah: Jurnal Studi Agama dan Pemikiran Islam Vol. 11, No. 1 (Maret 2013), h. 157. Lihat juga Muhammad Abu Zahrah, Ushul Fiqh, diterjemahkan oleh Saifullah Maksum dkk (Jakarta: Pustaka Firdaus, 2008), h. 293-294. 
kebaikan atau keburukannya. Misalnya, perkara beriman kepada Allah SWT, berbuat baik kepada kedua orang tua, jujur, adil, bohong, dan lain sebagainya. ${ }^{14}$ Hal ini juga ditegaskan oleh Adbul Wahhab Khallaf, menurutnya, nash yang mengandung masalahmasalah kewajiban beriman kepada Allah SWT, rasul, kitab-Nya, Hari Akhir, dan dasardasar akidah serta ibadah yang lain, tergolong dalam nash-nash yang mencakup hukum 'dasar' agama Islam yang tidak dapat berubah sebab perubahan kondisi manusia dan tidak berubah menjadi baik atau jelek sebab perbedaan tolak ukur. ${ }^{15}$ Ketiga, nash yang mengganti (naskh) turunnya harus lebih akhir dari nash yang diganti (mansūkh). Sebab, naskh berfungsi menggantikan berlakunya hukum yang terkandung dalam nash yang diganti (mansūkh). Selain itu, kedua nash tersebut harus sama tingkat kekuatannya. Keempat, naskh dilakukan hanya apabila kedua nash (naskh dan mansükh) benar-benar sudah tidak dapat dikompromikan.

Al-Zarqani juga menegaskan, naskh baru dapat dilakukan apabila terdapat dua ayat hukum yang saling bertolak belakang dan tidak dapat dikompromikan. Beliau kemudian menambahkan, bahwa, naskh baru bisa dilakukan manakala sudah diketahui

\footnotetext{
${ }^{14}$ Zahrah, Ushul Fiqh, h. 293

${ }^{15}$ Zahrah, Ushul Fiqh, h. 294
} 
Muhammad Nasrullah, Pandangan Abdullah Saeed Pada Konsep Naskh

secara meyakinkan tentang perurut an turunnya ayat-ayat tersebut, sehingga yang lebih dahulu ditetapkan sebagai mansūkh, dan yang kemudian sebagai naskh. ${ }^{16}$ Demikian juga Abd al-Rahman Ibn Ali Ibn Muhammad Ibn Jauziy mengajukan empat syarat boleh dilakukanya naskh, yaitu pertama, hukum syara' yang sudah berlaku dengan dalil syara'. Maksudnya, hukum yang di-naskh tersebut haruslah hukum syara', bukan hukum akal atau buatan manusia. Kedua, dalil syara' yang baru. Dalil untuk menghukum syara' itu harus dalil syara' juga. Ketiga, objek hukum yang sama. Maksudnya, afrad yang dicakup oleh hukum berdasarkan dalil syar'i yang pertama sama dengan afrad yang dicakup dalil syar'i yang terakhir datang. Dan jika objeknya berbeda sama sakali, maka tidak terjadi nasakh. Keempat, hukum yang baru. Pendapat mereka juga diperkuat oleh al-Qattan, menurutnya, al-naskh wa al-mansūkh dapat diketahui melalui: ${ }^{17}$

Pertama, terdapat keterangan yang tegas dari Nabi SAW atau sahabat. Contoh, Hadis Nabi SAW yang menjelaskan tentang

16 Abdul 'Azim al-Zarqani, Manahil A-'Irfan fi 'Ulum alQur'an, Jilid II (Mesir: Al Halabiy, 1980), h. 209.

${ }^{17}$ Baca al-Qattan, dalam Mhd Dongan, http://www.s cribd.com/doc/17347934/ Nasyikh-Dan-Mansyuk-Dalam-Alquran. 
nikah mut'ah, "Dari Rabi' ibn Sabrah bahwa ayahnya meyampaikan kepadanya: Rasullullah SAW bersabda:

Wahai sekalian manusia, saya dahulu mengizinkan kamu istimta' dengan wanita (nikah mut'ah), dan sekarang Allah telah mengharamkannya sampai hari kiamat. Siapa di antara kamu yang masih memiliki wanita mut'ah, lepaskanlah dan jangan minta lagi sedikitpun dari apa yang kamu berikan kepada mereka. ${ }^{18}$

Kedua, terdapat kesepakatan umat antara ayat nâsikh dan ayat yang di-mansûkh. Jika tidak ada nash yang menjelaskan secara langsung tent ang pembatalan atau perubahan hukum, tet api dapat dipahami langsung dari dalil-dalil tersebut, maka harus ada ijmak ulama yang menetapkan hal tersebut.

Ketiga, ada dua ayat yang bertentangan, dan diketahui mana yang pertama dan mana yang kedua.

Para ulama juga memberi pedoman ntuk mengetahui nasikh dan mansūkh dengan mengidentifikasi beberapa cara berikut:

${ }^{18}$ Muslim bin Hajjaj, Sohih Muslim Jllid 2 (Beirut: Dar alHadith, 2004), h. 56. 
Muhammad Nasrullah, Pandangan Abdullah Saeed Pada Konsep Naskh

1. Ada keterangan tegas atau pentransimisian yang jelas dari Nabi S.A.W atau sahabat seperti dalam redaksi hadits: (kuntu nahaitukum 'an ziyaratil qubuur alaa fazuuruuhaa), dan seperti ucapan Anas bin Malik dalam kisah Ashab Bi'r Ma'unah (nazala fiihim qur'an qara'naahu hatta rufi'a).

2. Konsensus (ijma') umat bahwa ayat ini nasikh dan ayat itu mansükh.

3. Mengetahui mana yang lebih dahulu dan mana yang belakangan berdasarkan histori. Histori ayat dapat diketahui dari keterangan sahabat, yang bukan ijtihad sahabat itu sendiri. Misalkan sahabat itu mengatakan: "Ayat ini turun pada tanggal, bulan atau tahun sekian, sedangkan ayat ini turun pada tanggal, bulan atau tahun sekian, jadi ayat ini lebih kemudian dari ayat itu" ${ }^{19}$

Secara umum terdapat 4 (empat) pola nāsikh - mansūkh yaitu: ${ }^{20}$

${ }^{19}$ Abdul Rahman Malik, "Abrogasi dalam Alquran: Studi Nasikh dan Mansukh" Jurnal Studi Al-Qur'an UIN Syarif Hidayatullah Vol. 12, No. 1 (2016), h. 101.

${ }^{20}$ Subaidi, “Historisitas Nasikh Mansukh Dan Problematikanya Dalam Penafsiran Al- Qur'an” Hermeneutik: Jurnal UNISNU Jepara Vol. 8, No. 1 (Juni 2014), h. 63. 
Volume 2, Number 2, Juli - Desember 2020

1. Al-Qur'an di naskh oleh al-Qur'an, ini disepakati oleh semua ulama' .

2. Al-Qur'an dinaskh dengan Sunnah, jenis ini ada dua model yaitu pertama, al-Qur'an dinaskh oleh hadis ahad yang dalam hal ini jumhur ulama menolak. Kedua, al-Qur'an di naskh oleh hadis mutawatir, dalam hal ini Imam Syaf'ai menolak, tetapi Imam Malik, Imam Abu Hanifah dan Imam Ahmad dalam suatu riwayat menerima $\mathrm{Na}^{-}$sikh al-Sunnah, $\mathrm{Mansu}^{-} \mathrm{kh}$ alQur'an.

3. Al-Sunnah dinaskh oleh al-Qur'an, dalam hal ini jumhur ulama' menerima dan sepakat.

4. Al-Sunnah di naskh oleh al-Sunnah, yang dalam hal ini ada 4 model : pertama, hadis mutawatir dinaskh oleh hadis mutawatir, kedua, hadis ahad dinaskh oleh hadis ahad, ketiga, hadis ahad dinaskh dengan hadis mutawatir dan keempat hadis mutawatir dinaskh dengan hadis ahad.

Dalam kitab Manna Al-Qaththan, tidak dijelaskan dengan jelas ayat mana saja yang sebenarnya berlaku nasikh - mansukh, hanya saja diberikan pedoman untuk mengetahui nasikh-mansukh. Pedoman untuk mengetahui nasikh-mansukh tersebut yakni: keterangan tegas dari hadis Nabi Muhammad atau sahabat, 
Muhammad Nasrullah, Pandangan Abdullah Saeed Pada Konsep Naskh

kesepakatan umat bahwa ayat tersebut di naskh, mengetahui ayat mana yang lebih dulu turun sesuai sejarah. Naskh tidak bisa ditetapkan berdasar ijtihad, pendapat mufassir, atau dalil-dalil yang secara lahiriyah tampak kontradiktif.

Diantara ayat-ayat yang dipetakan Manna Khalil alQattan yang berlaku baginya nasikh-mansukh adalah sebagai berikut: ${ }^{21}$

a. QS. Al-Mujadilah ayat 12 dihapus ayat 13

b. QS. Al-Baqarah ayat 183 dihapus ayat 187

c. Perintah shalat menghadap ke Baitul Maqdis dihapus dengan QS. Al-Baqarah ayat 144

d. QS. An-Nisa ayat 15 dihapus oleh QS. An-Nur ayat 2

e. QS. Al-Baqarah ayat 115 dihapus ayat 144

f. QS. Al-Baqarah ayat 180 dihapus QS. An-Nisa ayat 11

g. QS. Al-Baqarah ayat 184 dihapus ayat 185

h. QS. Al-Baqarah ayat 240 dihapus ayat 234

${ }^{21}$ Imam Masrur, “Konsep Nasikh Mansukh Jalaluddin Al-Suyuti Dan Implikasi Metode Pengajarannya Di Perguruan Tinggi," Realita: Jurnal STAIN Kediri Volume 16, No. 1 (2018), 7. 
Volume 2, Number 2, Juli - Desember 2020

i. $\quad$ QS. Al-Baqarah ayat 284 dihapus ayat 286

j. QS. Al-Anfal ayat 65 dihapus ayat 66.

Dari sini dapat diketahui bahwa, para ulama Islam sangat berhat-hati dalam melakukan naskh. Dari sisi kandungan ayat, mereka mengatakan bahwa, ada hukum-hukum yang terkandung dalam al-Qur'an dan sunnah yang tidak dapat di-nasakh, karena ia menyangkut masalah-masalah pokok (dasar) dalam Islam, seperti nash yang mengandung masalah-masalah kewajiban beriman kepada Allah SWT, rasul, kitab-Nya dan Hari Akhir, serta dasardasar akidah dan ibadah yang lain. Semua ayat yang mengandung hukum demikian sama sekali tidak dapat berubah walaupun terjadi perubahan kondisi manusia.

\section{Naskh Mansūkh Surah An-Nur Ayat 2 dan Problematikanya}

Berdasarkan uraian di atas,QS. An-Nisa ayat 15 dihapus oleh QS. An-Nur ayat 2 yang berisi tentang hukuman dera bagi pezina. Pada permulaan Islam, hukuman untuk tindak pidana zina adalah dipenjarakan di dalam rumah dan disakiti, baik dengan pukulan pada badannya maupun dengan dipermalukan. Dasarnya 
Muhammad Nasrullah, Pandangan Abdullah Saeed Pada Konsep Naskh

adalah firman Allah dalam Alquran surah An-Nisa' ayat 15 yang berbunyi:

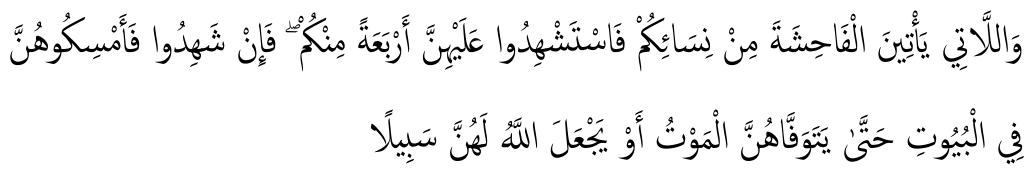

Terjemahannya: Dan (terhadap) para wanita yang mengerjakan perbuatan keji, hendaklah ada empat orang saksi diant ara kamu (yang menyaksikannya). Kemudian apabila mereka telah memberi persaksian, maka kurunglah mereka (wanitawanita itu) dalam rumah sampai mereka menemui ajalnya, atau sampai Allah memberi jalan lain kepadanya.

Setelah Islam mulai berkembang, terjadi perkembangan dan perubahan dalam hukuman zina ini, yaitu dengan turunnya Surah An-Nur ayat 2:

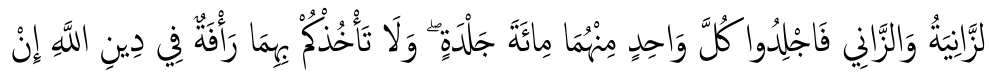

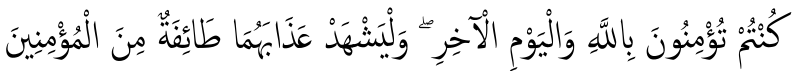

Terjemahannya: Perempuan yang berzina dan laki-laki yang berzina, maka deralah tiap-tiap seorang dari keduanya seratus dali dera, dan janganlah belas kasihan kepada keduanya mencegah kamu untuk (menjalankan) agama Allah, jika kamu beriman kepada Allah, dan hari akhirat, dan hendaklah 
(pelaksanaan) hukuman mereka disaksikan oleh sekumpulan orang-orang yang beriman.

Ayat di atas menerangkan hukum bagi pelaku zina bujang ataupun gadis di cambuk 100 kali, tidak boleh mendapat belas kasihan40 dan diasingkan selama satu tahun, sementara bagi pelaku zina muhsan akan diberi hukuman rajam (dilempari batu sammpai meninggal dan disaksikan orang banyak). Penggunaan batu kecil (kerikil) agar pelaku zina dapat merasakan sakitnya sedikit demi sedikit yang timbul dari penyiksaan tersebut. Hukum rajam hanya untuk pelaku zina yang mencukupi syarat-syarat muhsan, rajam bertujuan untuk membunuh pelaku zina. ${ }^{22}$

Adanya perbedaan antara hukuman ghairu muhsan dan muhsan ini karena diharapkan pelaku zina muhsan dapat menjaga diri untuk tidak melakukan perbuat an tercela, apabila pelaku zina (muhsan) masih ada ikatan perkawinan maka akan menyakiti pasangan sahnya dan mencemarkan nama baik keluarga. Tidak menutup kemungkinan hukuman dera dalam pelaksanaannya, dalam beberapa kasus ada yang mati sebelum target 100 kali dilaksanakannya. Penzina ghairu muhsan mendapat hukuman

${ }^{22}$ Sukarmi, "Pernikahan Akibat Zina Dalam Tafsir Ahkam (Analisis Tafsir Rawa'i Al-Bayan Fi Tafsir Ayat Al-Ahkam Min AlQur'an)" Skripsi: Universitas Islam Negeri Raden Intan Lampung (2019), h. 35-36. 
Muhammad Nasrullah, Pandangan Abdullah Saeed Pada Konsep Naskh

cabuk dan diberi kemudahan hukuman 1 tahun diasingkan. ${ }^{23}$ Para fuqaha dalam menanggapi hukuman diasingkan selama satu tahun berbeda pendapat.

Perasingan setahun merupakan tambahan hukuman cambuk. Dan banyak para ulama yang sependapat dengan Imam Ahmad. Khulafah Rassydin mengakatan bahwa perlu pengasingan untuk pelaku zina ghairu muhson. Dan menurut Imam Malik, beliau berpendapat bahwa hukuman pengasingan berlaku untuk laki-laki saja dan perempuan tidak. $^{24}$

Dari penjelasan pendapat-pendapat para ulama diatas hukuman dapat diterapkan apabila memperhatikan beberapa bukti. Yakni, Iqrar atau pengakuan orang dari pelaku atau dijelaskan, dan pengakuan dapat menjadi bukti hendaknya memenuhi tiga syarat, yaitu: ${ }^{25}$

1. Menyatakan dengan kesadaran sendiri ataupun tidak di paksa.

${ }^{23}$ Sukarmi, "Pernikahan Akibat Zina Dalam Tafsir Ahkam (Analisis Tafsir Rawa'i Al-Bayan Fi Tafsir Ayat Al-Ahkam Min AlQur'an)". h. 35.

${ }^{24}$ Sukarmi, "Pernikahan Akibat Zina Dalam Tafsir Ahkam (Analisis Tafsir Rawa'i Al-Bayan Fi Tafsir Ayat Al-Ahkam Min AlQur'an)", h. 35.

${ }^{25}$ Fatur Rahman, Hadis Tentang Peradilan Agama (Jakarta: Bulan Bintang, 1997), h. 20. 
Volume 2, Number 2, Juli - Desember 2020

e-ISSN 2716-4241

ISSN 2723-2344

2. Pengakuan yang dibuat bisa lisan ataupun tulisan dan harus lugas.

3. Terdapat empat orang saksi yang adil, sebagaimana yang telah disepakati dan dilakukan para sahabat terdahulu.

Hamka mengatakan bahwa ayat ini telah Mansūkh, telah dihapuskan hukumannya oleh hukuman zina razam yang disebutkan didalam surat An-Nur. Sebelum QS. An-Nur itu turun, hukumannya perempuan berzina ialah tahanan rumah, sampai mati. Tidak boleh keluar sama sekali. Kecuali kalau kelihatan mereka telah benar-benar taubat, baru dapat dikeluarkan. ${ }^{26}$

Kebanyakan mufassirin mengatakan, bahwa ayat 15 surah An-Nisa ini telah dimansükhkan oleh ayat 2 surah An-Nur. Akan tetapi, Abu Muslim berkata, bahwa ant ara kedua ayat ini tidak ada Nasikh dan Mansukh, melainkan lengkap-melengkapi. Menurut Abu Muslim perbuatan keji dalam ayat 15 surah An-Nisa ini ialah berzina sesama perempuan, yang di beri nama Musahaqah, yaitu

${ }^{26}$ Ruslan, "Nasikh dan Mansukh Alquran Menurut dr. Hamka," dalam Journal of Islamic and Law Studies Volume 3, Nomor 2 (Desember 2019), h. 8. 
Muhammad Nasrullah, Pandangan Abdullah Saeed Pada Konsep Naskh

mengadu faraj dengan faraj. Yang kalau di lakukan oleh sesama laki laki dinamai liwath. Dalam bahasa asing "HomoSexuality". ${ }^{27}$

Akan tetapi bagi ulama yang tidak menerima naskh mansūkh, Surah An-Nisa' ayat 15 tersebut tetap berlaku dan tidak dinasakh oleh Surah An- Nur ayat 2. Hanya saja penggunaan dan penerapannya yang berbeda. Surah An- Nisa' ayat 15 berlaku bagi wanita yang berhubungan intim dengan wanita (lesbian), sedangkan surah An-Nisa' ayat 16 berlaku bagi laki- laki yang berhubungan intim dengan laki- laki (homoseksual/ liwath), dan Surah An- Nur ayat 2 berlaku bagi laki-laki dan wanita yang berzina. ${ }^{28}$

Berdasarkan penjelasan diatas, pertama ayat Alquran menetapkan hukum kurungan bagi pelaku zina sampai ia meninggal, tujuannya adalah untuk mencegah agar pelaku zina tidak mengulangi perbuatnnya. Kedua hukum bagi pelaku zina diganti dengan hukuman cambuk sampai ia meninggal. Antara hukum pertama dan kedua tetap dalam tujuan yang sama yakni mencegah perbuatan yang tidak bermoral dan bertentangan

${ }^{27}$ Ruslan, "Nasikh dan Mansukh Alquran Menurut dr. Hamka,", h. 8 .

${ }^{28}$ Sayyid Sabiq, Fikih Sunnah (Yogyakarta: Al-Ma'arif, 2008), 343. 
dengan Islam. Artinya hukum kurungan atau cambuk bukanlah tujuan dari Alquran, kedua hukum tersebut hanyalah oprasional dari tujuan Alquran mencegah perbuatan yang dilarang Islam.

Dalam Kasus Zina surah An-Nur ayat 2 tersebut, Abdullah Saeed mengaskan dalam sebuah jurnal bahwa hukum yang terdapat dalam redaksi ayat harus dipahami terlebih dahulu apakah itu merupakan tujuan yang diinginkan oleh Alquran atau hanya sekedar sebagai oprasional dari tujuan Alquran, hal ini berguna untuk menemukan tujuan sesunguhnya yang diinginkan oleh Alquran, setelah diketahui apa yang menjadi tujuan dari Alquran langkah selanjutnya adalah melihat metode yang digunakan oleh Alquran untuk memperoleh tujuan, dan kondisi dan situasi harus selalu menjadi pertimbangan.

Menurut Abdullah Saeed naskh juga dapat menjadi solusi untuk memudahkan umat yang sering sekali mengalami kesulitan dalam membedakan antara hukum yang terdapat dalam teks dengan tujuan moral yang diinginkan oleh teks sehingga hukum yang terdapat dalam teks hanyalah sebagai salah satu alternatif untuk memperoleh tujuan moral. Karena dalam beberapa kasus naskh, menurut Saeed sebenarnya bukan tujuan dari hukum yang di naskh, artinya walaupun suatu ayat telah dinaskh namun antara 
Muhammad Nasrullah, Pandangan Abdullah Saeed Pada Konsep Naskh

ayat yang naskh dan mansükh tetap dalam tujuan yang sama, contoh seperti dalam kasus zina diatas.

Inti dari penjelasan adalah jika hukum yang tertulis dalam ayat diketahui hanya sebagai oprasional untuk memperoleh tujuan, ketika hukum tersebut sudah tidak lagi relevan dengan tujuan melihat dari kondisi dan situasi yang berbeda maka perlu adanya penafsiran ulang demi untuk mendapatkan tujuan yang sebenarnya diinginkan oleh Alquran. Dan hal tersebut telah ditunjukan oleh adanya konsep nasikh mansukh. ${ }^{29}$

\section{Konsep Naskh Mansūkh Abdullah Saeed}

Berdasarkan uraian Abdullah Saeed terhadap problematika naskh mansükh tentang ayat zina dalam Surah AnNur ayat2 diatas, Naskh mansūkh menurut Saeed adalah pembatalan hukum dan yang diinginkan Saeed adalah menekankan bahwa konsep naskh mansukh memberi gagasan yang sangat logis bahwa hukum yang berlaku bisa saja mengalami pembatalan demi untuk memenuhi kebut uhan umat karena kondisi dan situasi yang berbeda, jika dulu Alquran masih turun maka

29 Aavi Lailaa Kholily, "Pandangan Abdullah Saeed Pada Konsep Nasikh Mansukh," dalam Jurnal Nun: Jurnal Keislaman UIN Sunan Kalijaga Vol. 4, No.1 (2018), h. 176. 
solusi dari Allah untuk memenuhi kebutuhan umat adalah dengan membatalkan hukum yang sudah berlaku dengan menurunkan hukum baru atau nasikh mansukh, namun karena sekarang ayat Alquran sudah lagi turun maka untuk memenuhi kebutuhan umat adalah dengan cara menafsiri ulang Alquran.

Jadi Naskh secara terminologi adalah menurut Saeed adalah pencabutan suatu hukum dengan hukum yang datang setelahnya, pendapat ini beliau sandarkan dari beberapa ayat Alquran.

Pendapat Abdullah Saeed ini juga disepakati oleh jumhurul Ulama'. Menurut Jumhur dalam faktanya hukum-hukum Alquran memang telah mengalami pencabutan, walaupun terkadang pencabutan diganti dengan hukum yang sangat berbeda. ${ }^{30}$

Pada suatu sumber, Abdullah Saeed masih merujuk pada pendapat jumhur ulama' tanpa memberikan pendapatnya sendiri. Namun kemudian Saeed membagi lagi pada ayat-ayat yang dinasikh menjadi tiga hal, yakni nasikh hukum sekaligus bacaan, nasikh hukum tetapi bacaannya tetap dan nasikh bacaan namun

${ }^{30}$ Lien Iffah Naf'atu Fina, Penafsiran Kontekstualis Atas AlQur'an (Yogyakarta: Lembaga Ladang Kata, 2016), h. 151. 
Muhammad Nasrullah, Pandangan Abdullah Saeed Pada Konsep Naskh

hukumnya masih tetap berlaku. Pendapat ini walaupun dalam bukunya Saeed tidak menyantumkan catatan kaki sebagaimana keterangan yang Saeed jelaskan terkait pengertian nasikh dan bentuk-bentuknya. Namun dalam sebuah penelitian pernyatan Abdullah Saeed tersebut tertulis dalam kitab Tahqiqat yang merupakan salah satu dari ulama' ushul dan dijelaskan pula oleh Khalil al-Qaththan dalam Mabahis fi Ulumil Qur'an. Yang artinya, bahwa dengan adanya hal tersebut menunjukan Saeed masih sependapat dengan pendapat jumhurul ulama'. ${ }^{31}$

Konsep naskh menurut Saeed sendiri adalah sebuah gagasan yang dapat menjadi sandaran perkembangnya hukum dalam Alquran, maksudnya dengan adanya naskh Alquran sejak masa Rasulullah Allah telah menunjukan adanya perubahan hukum yang sebelumnya telah ditetapkan sesuai dengan kondisi dan situasi yang berbeda.

Konsep yang dibangun Abdullah Saeed inilah yang menjadi pembeda antara pendapatnya dengan pendapat para jumhur ulama'. Jumhur ulama' sepakat dengan adanya naskh mansūkh tetapi mereka memiliki kriteria bahwa ayat atau hukum bisa dikatakan di nasikh dengan hukum yang lain harus dengan

${ }^{31}$ Aavi Lailaa Kholily, “Pandangan Abdullah Saeed”, h. 172. 
adanya nash - nash dari Alquran atau hadis yang mengindikasikan adanya naskh, seperti terdapat kontradiksi antara dua hukum namun harus diketahui mana yang lebih dahulu ditetapkan, ada penjelasan tegas dari nabi shahabat bahwa hukum tersebut di naskh dan terakhir harus mendapat kesepakatan atau ijma' yang mengatakan bahwa hukum tersebut di naskh selain dari itu hukum tidak bisa bisa dikatakan sebagai telah menaskh atau dimansūkh. ${ }^{32}$

Saeed justru malah menjadikan naskh mansūkh sebagai pijakan awal untuk mengkontekstualisasikan hukum Alquran dengan melihat kondisi dan situasi yang terjadi. Walaupun Saeed tidak mengatakan bahwa hasil dari kontekstualisai hukum berarti menjadi nasikh, namun perubahan hukum yang terjadi lewat adanya nasikh mansukh pada saat itu menurutnya bisa menjadi alasan perubahan hukum untuk konteks sekarang dengan melihat kondisi dan situasi saat ini dan alasan itu tidak digunakan oleh jumhurul ulama'.

\section{Penutup}

Berdasarkan hasil pemaparan diatas, Naskh secara terminologi menurut Abdullah Saeed adalah pencabutan dari

${ }^{32}$ Kholily, “Pandangan Abdullah Saeed”, h. 172. 
Muhammad Nasrullah, Pandangan Abdullah Saeed Pada Konsep Naskh

suatu hukum dengan hukum yang datang setelahnya. Menurut Saeed, Konsep naskh mansūkh memberi gagasan yang sangat logis bahwa hukum yang berlaku bisa saja mengalami pembatalan demi untuk memenuhi kebutuhan umat karena kondisi dan situasi yang berbeda, jika dulu Alquran masih turun maka solusi dari Allah untuk memenuhi kebutuhan umat adalah dengan membatalkan hukum yang sudah berlaku dengan menurunkan hukum baru atau nasikh mansukh, namun karena sekarang ayat Alquran sudah lagi turun maka untuk memenuhi kebutuhan umat adalah dengan cara menafsiri ulang Alquran.

Abdullah Saeed juga merujuk pada pendapat jumhur ulama' tanpa memberikan pendapatnya sendiri. Namun kemudian Saeed membagi lagi pada ayat-ayat yang dinasikh menjadi tiga hal, yakni nasikh hukum sekaligus bacaan, nasikh hukum tetapi bacaannya tetap dan nasikh bacaan namun hukumnya masih tetap berlaku.

Untuk mengkontekstualisasikan hukum Alquran dengan melihat kondisi dan situasi yang terjadi, Abdullah Saeed menjadikan naskh mansūkh sebagai sebuah langkah awal dalam mengkontekstualisasikan hukum Alquran. 
Volume 2, Number 2, Juli - Desember 2020

\section{Daftar Pustaka}

Abu Zahrah, Muhammad. Ushul Fiqh, diterjemahkan oleh Saifullah Maksum dkk, Jakarta: Pustaka Firdaus, 2008.

Ali, Zainudin. Hukum Pidana Islam, Jakarta: Sinar Grafika, 2009. Al-Lathowi, Hasan Kamil. Fiqh Muamalah ala Madzhab al Imam Malik, Beirut: Toba'ah al-Aula, 1970.

Al-Qattan, Manna Kholil. Pengantar Studi Ilmu Al-Qur'an, Jakarta:Pustaka Al-Kaustar, 2008.

Al-Zarqani, Abdul 'Azim. Manahil A-'Irfan fi 'Ulum al-Qur'an, Jilid II, Mesir: Al Halabiy, 1980.

Asmu'i. "Studi Kritis Atas Konsep Nâsikh-Mansûkh Abdullahi Ahmed An-Na'im", Kalimah: Jurnal Studi Agama dan Pemikiran Islam, Vol. 11, No. 1, ed. Maret 2013.

Fina, Lien Iffah Naf'atu. Penafsiran Kontekstualis Atas AlQur'an, Yogyakarta: Lembaga Ladang Kata, 2016.

Kholily, Aavi Lailaa. "Pandangan Abdullah Saeed Pada Konsep Nasikh Mansukh", Nun: Jurnal Keislaman UIN Sunan Kalijaga, Vol. 4, No.1, 2018.

Malik, Abdul Rahman. "Abrogasi dalam Alquran: Studi Nasikh dan Mansukh", Jurnal Studi Al-Qur'an UIN Syarif Hidayatullah, Vol. 12, No. 1, 2016.

Masrur, Imam. “Konsep Nasikh Mansukh Jalaluddin Al-Suyuti Dan Implikasi Metode Pengajarannya Di Perguruan Tinggi", Realita: Jurnal STAIN Kediri, Vol. 16, No. 1, 2018. 
Muhammad Nasrullah, Pandangan Abdullah Saeed Pada Konsep Naskh

Muchlisin, Annas Rolli. "Penafsiran Kontekstual: Studi Atas Konsep Hierarki Nilai Abdullah Saeed', Maghza: Jurnal UIN Sunan Kalijaga Yogyakarta, Vol. 1, No. 1, JanuariJuni 2016.

Mustofa, Imron. "Kritik Metode Kontekstualisasi Penafsiran AlQur'an Abdullah Saeed', Islamica: Jurnal Studi Keislaman, Vol 10, No. 2, 1 Maret 2016.

Rahman, Fatur. Hadis Tentang Peradilan Agama, Jakarta: Bulan Bintang, 1997.

Ruslan. "Nasikh Dan Mansukh Alquran Menurut dr. Hamka", Journal of Islamic and Law Studies UIN Antasari, Volume 3, Nomor 2, Desember 2019.

Sabiq, Sayyid. Fikih Sunnah 4, Jakarta: Cakrawala Publishing, 2009.

Fikih Sunnah II, Yogyakarta: Al-Ma'arif, 2008.

Salih, Subhi. Mabahis fii Ulum al-Qur'an, Beirut: Dar al-'Ilm lil Malayin, 1988

Sovia, Sheyla Nichlatus. "Interpretasi Kontekstual: Studi Pemikiran Hermeneutika Al-Qur'an Abdullah Saeed', Dialogia: Jurnal Studi Islam dan Sosial IAIN Pomorogo, 2016.

Subaidi. "Historisitas Nasikh Mansukh Dan Problematikanya Dalam Penafsiran Al- Qur'an", Hermeneutik: Jurnal UNISNU Jepara, Vol. 8, No. 1, Juni 2014.

Sukarmi. "Pernikahan Akibat Zina Dalam Tafsir Ahkam (Analisis Tafsir Rawa'i Al-Bayan Fi Tafsir Ayat Al-Ahkam Min 
Volume 2, Number 2, Juli - Desember 2020 e-ISSN 2716-4241

ISSN 2723-2344 Al-Qur'an)", Skripsi: Universitas Islam Negeri Raden Intan Lampung, 2019.

Supiana dan M. Karman. Ulumul al-Quran dan Pengenalan Metode Tafsir, Bandung: Pustaka Islamika, 2002. 